\title{
Brand-switching and tobacco taxation in Vietnam
}

\author{
Anh Nguyen ำ , Hoang Nguyen The, Nuong Ai Nguyen
}

- Additional supplemental material is published online only. To view, please visit the journal online (http://dx.doi. org/10.1136/tobaccocontrol2021-056821).

Development and Policies Research Center, Hanoi, Viet Nam

\section{Correspondence to}

Dr Anh Nguyen, Development and Policies Research Center, Hanoi, Viet Nam; anhnguyen@depocen.org

Received 31 May 2021 Accepted 11 October 2021

Check for updates

(c) Author(s) (or their employer(s)) 2021. No commercial re-use. See rights and permissions. Published by BMJ.

To cite: Nguyen A, Nguyen The $\mathrm{H}$, Nguyen NA.

Tob Control Epub ahead of print: [please include Day

Month Year]. doi:10.1136/

tobaccocontrol-2021-056821

\section{ABSTRACT}

Background The government of Vietnam is embarking on a radical tobacco excise tax reform, switching from the current pure ad valorem scheme to a mixed system by adding a specific component. There have been concerns raised by state-owned tobacco companies against this initiative that switching to a mixed scheme may shift consumption away from cheaper, domestic brands to more expensive, foreign brands (produced locally by joint ventures between multinational tobacco companies and domestic firms) and to illicit cigarettes, thus impairing the domestic industry, rather than reducing cigarette consumption effectively. Unfortunately, although this concern has been one of the biggest obstacles to the tobacco tax reform in the country, no study thus far has attempted to address it due mostly to the unavailability of relevant micro-market data with detailed information on brand choice.

Objectives This research attempts to study cigarette brand substitution patterns and quantify the potential effect of the proposed tax structure change on cigarette brand choice to inform tax policy discussions in Vietnam.

Methods A discrete choice experiment is conducted to collect data on smokers' stated brand choice when cigarette prices change exogenously. Combined with data on their current cigarette consumption, random parameter logit models were estimated and then used to calculate brand-level price semielasticities as well as numerically simulate the impact of tax reforms on smoking.

Results Smokers are more likely to substitute a lowpriced domestic brand with another domestic brand than either with a foreign brand or with an illicit brand, both of which are more expensive. Furthermore, the opt-out is one of the closest substitutes to low-priced brands and also the most sensitive to a change in their prices, implying that smokers of low-priced brands are more likely to buy none of the studied brands when cigarette prices increase. This provides strong suggestive evidence that they appear more likely to stop smoking when faced with higher cigarette prices. Imposing a specific tax tends to reduce the market share for both low-priced and high-priced licit brands, although the estimated market share reduction is larger for the former. In response to specific tax increases, a large share of current smokers do not intend to switch to illegal cigarette brands, but rather choose none of the experimented brands, suggesting their intention to quit. Finally, the magnitude of substitution to illicit brands tends to be negatively related to change in their prices as a result of the specific excise tax hike.

Conclusion Contrary to the raised concern, smokers are more likely to substitute a domestic brand with another domestic brand than with a foreign brand. Moreover, the threat of illicit trade should not be exaggerated, and there are actions that the government of Vietnam can take to mitigate the threat effectively.

\section{INTRODUCTION}

Tobacco products in Vietnam are subject to excise tax, which is purely ad valorem and based on factory gate price, rather than retail price. The ad valorem rate has been increased on several occasions, including to $70 \%$ in 2016 and most recently to $75 \%$ in 2019 . Because the tax base is ex-factory price, however, the total tobacco tax is estimated to account for only about $36.7 \%$ of the retail price of the most popular cigarette brand in 2018, which is relatively low. ${ }^{1}$ Thus, to make tobacco taxation more effective, the Ministry of Finance of Vietnam presented a proposal to switch to a mixed tobacco excise tax system in which a specific rate will be imposed on top of the ad valorem tax. In the draft proposal in 2017, a specific tax rate of 1000 Vietnamese dong (US\$0.043) was proposed and would be added to the tobacco excise in 2020. As of August 2021, nevertheless, due to a number of factors, including the COVID-19 pandemic, it has yet to be considered by the National Assembly.

The tobacco industry, most of whom are stateowned enterprises belonging to the Vietnam Tobacco Corporation (Vinataba), has opposed this proposal and argued that switching to a mixed scheme is unfair for domestic companies, all of which are state-owned. ${ }^{2}$ It is argued that the increase in prices induced by adding the specific tax component may shift consumption away from cheaper, domestic brands to more expensive, foreign brands produced by joint ventures between multinational tobacco companies and domestic firms, and to illicit cigarettes, thereby adversely affecting the domestic industry without effectively reducing overall cigarette consumption. Although this argument is one of the biggest obstacles to the tobacco tax reform in the country, to the best of our knowledge, no study has thus far attempted to address it to inform tax policy discussions. This is due mostly to the unavailability of relevant micro-market data with detailed information on brand choice.

This research attempts to bridge this gap and quantify the potential effect of different specific tax rates on cigarette brand choice by conducting a discrete choice experiment. This is a stated preference method and has gained popularity in studying smoking behaviour and the effect of tobacco control policies on tobacco use, mainly in the USA and other high-income countries. ${ }^{3}$ Recent contributions focus on cigarette packaging ${ }^{4}$ and electronic cigarettes. $^{5-7}$ Since stated preference data are collected through an experiment, price and other attributes can be manipulated so as to have a sufficient degree of variation for the estimation purpose, which may not be available in the actual market data. ${ }^{89}$ This advantage is particularly relevant to the context of the cigarette market in Vietnam, where brandlevel market data are scant and price-based policy 
changes have not taken place until recently. Moreover, it allows for estimating brand-level price semielasticities as well as numerically simulating the impact of tax reforms on smoking.

Previous studies have found that smokers may substitute between cigarette brands to mute the impact of a price increase instead of quitting, ${ }^{10}$ particularly in developing countries. ${ }^{11-14}$ Low-priced cigarettes can also be more affected by the specific tax than high-priced brands. ${ }^{15}$ Nevertheless, the specific tax can be more effective in reducing cigarette consumption as it tends to raise overall cigarette price levels more than does the ad valorem. ${ }^{15}$ Furthermore, illicit cigarettes are generally more expensive than their licit counterparts in Vietnam, unlike many other countries where the former are typically cheaper than the latter so that the threat of rising illicit trade needs to be assessed separately.

\section{EXPERIMENT DESIGN}

In order to examine brand-switching behaviour and make accurate predictions of brand-level cigarette demand, this study uses the labelled choice experiment. ${ }^{16}$ Each cigarette brand serves as an alternative label. Among many different brands currently sold in the market, 15 brands with varying prices are selected and subdivided into three regions: 5 licit brands and 1 illicit brand in the North; 5 licit brands and 1 illicit brand in the Central; and 5 licit brands and 3 illicit brands in the South, which account for a majority of national illicit cigarette consumption. ${ }^{17}$ In each region, the selected licit brands include both domesticowned and foreign-owned brands (both of which are produced in Vietnam), represent the market's price spectrum, from very cheap to premium products, and are among the most popular brands, while three selected illicit brands account for a predominant share of the total illicit cigarette trade in the country. ${ }^{16}$ Together, they account for over $80 \%$ market share, which is defined as the number of surveyed smokers consuming the brand as the percentage of the total number of smokers surveyed in the region.

In addition to the cigarette brand, price is the only attribute in the design. The Ministry of Finance proposed a specific component of 1000 Vietnamese dong (US\$0.043). However, international health organisations suggested that it would be too modest and the rate should be at least 2000-5000 Vietnamese dong (US\$0.087-0.217) to bring about significant changes in tobacco use. ${ }^{18}$ Thus, each licit brand has four price levels in our experiment, reflecting these four different values of specific tobacco excise tax: (1) no specific tax, (2) 1000 Vietnamese dong, (3) 2000 Vietnamese dong and (4) 5000 Vietnamese dong. The price levels of each legal cigarette brand are determined by adding different specific tax rates to its current median retail price that was obtained from a retailer survey conducted in April 2019 by the Development and Policies Research Center (DEPOCEN) (see online supplemental appendix A for a brief description). Since different brands have different current prices, the price levels vary across the brands. For simplicity, the price of the illicit cigarette brands is fixed throughout the experiment as they are not subject to the excise tax in principle.

The 'none of these' opt-out is included to allow smokers to choose not to buy any of the included brands. Changes in the number of smokers who would opt out in response to higher cigarette prices induced by tax increases can provide suggestive evidence of smokers' intention to quit smoking. Obtained evidence, if any, is suggestive because 'opting out' or refusing to purchase any brand could indicate that a smoker intends to quit or that she/he delays the purchase to seek a brand not
Case 1:

Which cigarette brand would you choose if their prices are given as following?

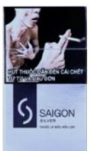

12.000 d

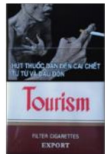

$7.000 \mathrm{~d}$
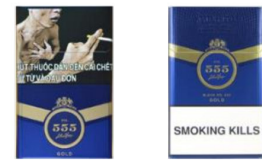

35.000 đ

$40.000 \mathrm{~d}$
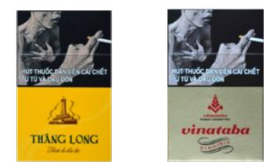

22.000 d

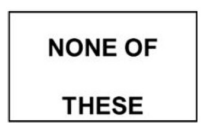

Figure 1 A sample of choice scenarios.

included in the design. The latter however is less likely because the included brands already cover over $80 \%$ of the total cigarette market. Furthermore, surveyed smokers are specifically instructed to imagine that only the experimented brands are sold, that is, there is no cigarette brand other than them available in the market. The inclusion of the opt-out also makes the experiment more realistic.

The full factorial design has $4^{5}=1024$ possible choice situations, which are impractically large to undertake. Thus, we adopt the smallest main effects-only orthogonal fractional factorial design, ${ }^{9} 16$ which comprises only 16 choice sets (see online supplemental appendix A for more details). Not only does the design reduce the number of choice sets, it also possesses desirable statistical properties, including balanceness, orthogonality and non-overlapping. The design then is randomly partitioned into two smaller, mutually exclusive blocks, each of which has eight choice sets. One holdout choice set is also added to each block to help respondents familiar with the experiment but dropped in estimation. In total, each respondent is required to answer nine questions in one block which is randomly assigned to him or her. SPSS V.20 software was used to generate these choice sets. A sample of choice sets is presented in figure 1 .

The choice experiment is administered to a sample of more than 1200 current smokers (400 in each of the three socioeconomic regions: North, Central and South) through a face-toface household survey in August-September 2019. The target participant pool comprises men and women aged 18 or older who smoke cigarettes at least once per week and within the last 3 months at the time of the survey. Multistage clustered and stratified sampling is used to randomly select participants in six provinces, which altogether account for roughly $18 \%$ of the total number of smokers in the country according to Global Adult Tobacco Survey (GATS) 2015 data. In addition to the stated preference data, the survey collects data on smokers' actual cigarette consumption and sociodemographic characteristics.

\section{DATA ANALYSIS}

Among a variety of discrete choice models, the random parameter logit (RPL) model is selected to analyse data collected from the choice experiment. By allowing different smokers to have different price coefficients, RPL is capable of capturing unobserved individual-specific taste heterogeneity. To ensure that the price coefficient is always negative, it is assumed to follow a log-normal distribution. The models estimated on the stated preference data, however, are not directly used to simulate the tax impacts. Instead, the alternative-specific constants (ASCs) are calibrated on the actual choice (revealed preferences) data 
before being used to calculate price semielasticities and undertake impact forecasting exercises. More details on the model specification can be found in online supplemental appendix B.

In addition to smoker behaviour, the impact of a tax increase on consumption also depends on the strategic responses of tobacco companies. Empirical results in the USA support both undershifting, ${ }^{19}{ }^{20}$ complete pass-through ${ }^{21} 22$ and overshifting, ${ }^{23}{ }^{24}$ with the estimated pass-through rate varying from $80 \%$ to $120 \%$. Across brands, some find similar estimates across price classes, ${ }^{202123}$ while others show that the pass-through rate for discount brands is 10 percentage points higher than that for premium brands. ${ }^{19}$ Among low- and middle-income countries (LMICs), about $80 \%$ the tax increase are transmitted to retail price in Pakistan over the period of 2004-2015, and the pass-through rate varies across price segments with complete pass-through for premium and only about $73 \%$ for low-priced brands. $^{25}$

Cross-border shopping also determines the impact of the tax reform. The assumption underlying the design of the choice experiment is that prices of illicit cigarettes are unaffected by the tax increases as they are not taxed. However, it is possible that their price may respond (likely increase) to higher prices of licit brands induced by a higher tax. Therefore, the analysis also includes scenarios that the price of the illicit brands would go up by $50 \%$ of the specific excise tax increase. To this end, it is implicitly assumed that smokers are equally sensitive to a change in the prices of illicit and licit brands. Furthermore, this implies that the analysis is predicting outside the observed price range, which may raise a concern about the accuracy of prediction. Nevertheless, it produces a useful comparison as illicit trade is often cited by the tobacco industry as an obstacle to tax increases.

Given the mentioned considerations, four scenarios are examined in our numerical impact simulation. The first case, that is, the baseline, assumes that the tax is completely passed through to the consumer price for all licit brands, while the price of illicit cigarettes is not affected. In the second, the pass-through rate is also $100 \%$ for all licit brands, but the price of illicit cigarettes increases by $50 \%$ of the tax increase. In the third, the taxes are undershifted with a pass-through rate of $80 \%$ for the low-priced licit brands and are completely passed through for the highpriced licit brands, while the price of illicit cigarettes remains unchanged. In the fourth, the taxes are undershifted with a passthrough rate of $80 \%$ for both the low-priced and high-priced licit brands, while the price of illicit cigarettes increases by $50 \%$ of the specific tax rates.

Since the models are estimated at the regional level, aggregation must be undertaken to derive national-level results. To do so, data on the shares of cigarette smokers by each region from GATS 2015 are used. The national change in brand-level share is the weighted sum of brand-level share in regional markets, with weights being the regional share of smokers in the national market.

\section{RESULTS}

Table 1 reports a summary of the sample demographics. After accounting for missing data, the final sample used in the analysis consists of 1151 smokers. Consistent with GATS 2015, majority of the smokers are male, with an average age of over 45. Education attainment in our sample appears to be slightly higher than in GATS 2015, likely reflecting the broad-based improvement in access to education in Vietnam. The average monthly income is about 7.34 million Vietnamese dong (US\$318.4), which is

\begin{tabular}{|c|c|c|c|c|}
\hline \multirow[b]{2}{*}{ Variables } & \multirow{2}{*}{$\begin{array}{l}\text { Our sample } \\
\text { Mean }\end{array}$} & \multirow[b]{2}{*}{ SD } & \multirow{2}{*}{$\begin{array}{l}\text { GATS } 2015 \\
\text { Mean }\end{array}$} & \multirow[b]{2}{*}{ SD } \\
\hline & & & & \\
\hline Male & 0.965 & & 0.975 & \\
\hline Age & 45.39 & 12.79 & 41.7 & 14.0 \\
\hline \multicolumn{5}{|l|}{ Education } \\
\hline Primary school or less & 0.315 & & 0.424 & \\
\hline Lower secondary school & 0.298 & & 0.299 & \\
\hline High school & 0.214 & & 0.158 & \\
\hline Tertiary education & 0.173 & & 0.118 & \\
\hline $\begin{array}{l}\text { Average monthly income } \\
\text { (Vietnamese dong, in million) }\end{array}$ & 7.342 & 10.34 & $\mathrm{~N} / \mathrm{A}$ & \\
\hline $\mathrm{n}$ & 1151 & & 1956 & \\
\hline
\end{tabular}

close to the average monthly income of male wage/salary earners (6.75 million Vietnamese dong or US\$292.8) in the national labour force survey in the third quarter of 2019, when the experiment was conducted on the field. These suggest that our sample is relatively representative.

The market share of a brand in a given region is defined as the number of surveyed smokers choosing the brand as the percentage of the total number of smokers surveyed in the region. This definition of market share is used to be consistent with the discrete choice experiment, in which smokers are asked to choose cigarette brands, but not the number of cigarettes. In other words, this study focuses only on the extensive margin, not smoking intensity or intensive margin. Following this definition, the considered brands account for an over $80 \%$ market share in the actual market. To facilitate the discussion, and based on price distribution, 15 brands under consideration are categorised into two price-based segments: (1) low-priced segment, with price less than 15000 Vietnamese dong (US\$0.651); and (2) high-priced segment, with price equal to 15000 Vietnamese dong or higher (table 2). All low-priced brands are domestic, while all high-priced brands are foreign, except for Vinataba, which is domestic. While three illicit cigarette brands fall into the high-priced segment, we analyse them separately and refer this segment to only the high-priced legal brands throughout this paper.

The results on the stated preferences data are presented in table 3. Following standard practice, parameter estimate columns (1), (3) and (5) report the mean $b$ and standard deviation $s$ of the $\log$ of the random price coefficient. The mean $\beta$ of the random price coefficient, which is recovered by applying the transformation $\beta=\exp \left(b+s^{2} / 2\right)$, is reported in the mean price coefficient columns (2), (4) and (6). All brand-specific dummies are interacted with smokers' income and age. The SD of the log of the price coefficient is highly significant, suggesting the existence of heterogeneous price disutility among smokers.

The ASCs are then calibrated on actual cigarette consumption data, and 'table 4 reports a matrix of semielasticities based on the calibrated model. Each semielasticity represents the percentage change in the market share of the row brand with respect to an increase of 1000 Vietnamese dong (US\$0.043) in the price of the column brand. Clearly, smokers are more likely to substitute a low-priced domestic brand with another domestic brand than either with a foreign brand or with an illicit brand, both of which are more expensive. For example, when Sai Gon's price increases by 1000 Vietnamese dong, the number of smokers of Hoa Binh, 
Table 2 Mean prices and market shares of experimental brands

\begin{tabular}{|c|c|c|c|c|c|c|}
\hline & \multicolumn{2}{|l|}{ North } & \multicolumn{2}{|l|}{ Central } & \multicolumn{2}{|l|}{ South } \\
\hline & $\begin{array}{l}\text { Price ('000 } \\
\text { Vietnamese dong) }\end{array}$ & Market share (\%) & $\begin{array}{l}\text { Price ('000 } \\
\text { Vietnamese dong) }\end{array}$ & Market share (\%) & $\begin{array}{l}\text { Price ('000 } \\
\text { Vietnamese dong) }\end{array}$ & Market share (\%) \\
\hline \multicolumn{7}{|l|}{ Low price } \\
\hline Tourism & $6.8(0.12)$ & $1.3(0.01)$ & & & & \\
\hline Prince & & & $7.8(0.14)$ & $18.3(0.36)$ & & \\
\hline Khanh Hoi & & & & & $8.3(0.44)$ & $1.6(0.01)$ \\
\hline Bastos & & & $10.1(0.35)$ & $4.2(0.04)$ & & \\
\hline Thang Long & $10.0(0.14)$ & $64.7(1.58)$ & & & & \\
\hline Sai Gon & $10.8(0.16)$ & $7.8(0.11)$ & $10.6(0.09)$ & $12.2(0.20)$ & $10.8(0.17)$ & $11.7(0.19)$ \\
\hline Hoa Binh & & & & & $10.9(0.12)$ & $3.9(0.04)$ \\
\hline \multicolumn{7}{|l|}{ High price } \\
\hline Craven $\mathrm{A}$ & & & & & $18.1(0.69)$ & $8.6(0.12)$ \\
\hline Vinataba & $19.9(0.67)$ & $11.4(0.19)$ & & & & \\
\hline White Horse & & & $23.6(0.33)$ & $43.7(1.11)$ & & \\
\hline Legal SE555 & $32.4(2.83)$ & $2.1(0.02)$ & $29.0(1.09)$ & $1.9(0.01)$ & $29.8(0.63)$ & $3.1(0.03)$ \\
\hline \multicolumn{7}{|l|}{ Illicit } \\
\hline Hero & & & & & $16.0(0.21)$ & $16.6(0.32)$ \\
\hline Jet & & & & & $19.6(0.10)$ & $35.6(0.87)$ \\
\hline Illicit SE555 & $38.4(1.28)$ & $4.2(0.04)$ & $40.1(1.94)$ & $1.9(0.01)$ & $36.8(1.18)$ & $1.0(0.01)$ \\
\hline Other brands & $21.9(1.37)$ & $8.6(0.12)$ & $14.9(1.00)$ & $18.0(0.36)$ & $9.7(0.67)$ & $17.9(0.35)$ \\
\hline$n$ & 385 & 385 & 378 & 378 & 385 & 385 \\
\hline
\end{tabular}

According to the World Bank, the average official exchange rate in 2019 was 1.00 Vietnamese dong $=$ US $\$ 4.34 \times 10^{-5}$ or US $\$ 1.00=23050.24$ Vietnamese dong.

SE in parentheses.

another domestic brand, would increase by over $15 \%$, compared with only an over $2 \%$ increase in the number of smokers of Craven A, a high-priced, foreign brand, or about 7\% increase in those of Hero, a popular illicit cigarette brand in the South. Similarly, for an increase of 1000 Vietnamese dong in Craven A's price, the number of smokers choosing Hoa Binh would increase by less than $2 \%$, much less than the over $15 \%$ when the price of Sai Gon rises by the same amount. Furthermore, the optout is one of the closest substitutes to low-priced legal brands and also the most sensitive to a change in their prices, implying that smokers of low-priced legal brands are more likely to buy none of the studied brands when cigarette prices increase. This provides strong suggestive evidence that they appear more likely to stop smoking when faced with higher cigarette prices.
Numerical simulation results based on the calibrated model are reported in table 5. Each number indicates a change (in percentage points) in market share for a corresponding cigarette brand segment, and one percentage point amounts to $1 \%$ of the total number of current smokers. As expected, imposing a specific tax tends to reduce the market share for both low-priced and high-priced licit brands, although the estimated market share reduction is larger for the former. Additionally, a large share of current smokers do not intend to switch to illegal cigarette brands in response to specific tax increases. In our baseline scenario where the entire tax increases are transmitted to retail prices and the price of the illicit brands remains unchanged, if the 5000 Vietnamese dong specific tax is imposed, it is estimated that nearly $15 \%$ of current smokers $(11.9 \%$ for low-priced legal

Table 3 Results from the random parameter logit model

\begin{tabular}{|c|c|c|c|c|c|c|c|}
\hline \multirow[b]{3}{*}{ Variables } & & (1) & (2) & (3) & (4) & (5) & (6) \\
\hline & & \multicolumn{2}{|l|}{ North } & \multicolumn{2}{|l|}{ Central } & \multicolumn{2}{|l|}{ South } \\
\hline & & Parameter estimates & $\begin{array}{l}\text { Mean price } \\
\text { coefficient }\end{array}$ & Parameter estimates & $\begin{array}{l}\text { Mean price } \\
\text { coefficient }\end{array}$ & Parameter estimates & $\begin{array}{l}\text { Mean price } \\
\text { coefficient }\end{array}$ \\
\hline \multirow[t]{4}{*}{ Price } & $b$ & -1.226 & -0.486 & -1.373 & -0.441 & -1.230 & -0.565 \\
\hline & & $(0.061)$ & $(0.042)$ & $(0.088)$ & $(0.039)$ & $(0.110)$ & $(0.043)$ \\
\hline & $s$ & 1.005 & & 1.052 & & 1.148 & \\
\hline & & $(0.056)$ & & $(0.077)$ & & $(0.082)$ & \\
\hline ASC & & Yes & & Yes & & Yes & \\
\hline Demographics $\times$ ASC & & Yes & & Yes & & Yes & \\
\hline Log likelihood & & -3088 & & -3009 & & -4136 & \\
\hline Number of choice tasks per person & & 8 & & 8 & & 8 & \\
\hline Number of participants & & 386 & & 380 & & 385 & \\
\hline
\end{tabular}

Parameter estimate columns report the mean $b$ and standard deviation $\mathcal{s}$ of the log of the random price coefficient. Then the mean $\beta$ of the random price coefficient is recovered by applying the

transformation $\beta=\exp \left(b+s^{2} / 2\right)$ and reported in the mean price coefficient columns.

Robust SE in parentheses.

ASC, alternative-specific constant. 
Table 4 Estimated semielasticities based on the calibrated random parameter logit model

\begin{tabular}{|c|c|c|c|c|c|c|}
\hline Region & Brand & Sai Gon & Thang Long & Tourism & Vinataba & Legal SE555 \\
\hline \multirow[t]{8}{*}{ North } & Sai Gon & $\begin{array}{l}-29.70 \\
(-31.77 \text { to }-27.62)\end{array}$ & $\begin{array}{l}23.73 \\
\text { (21.58 to } 25.87 \text { ) }\end{array}$ & $\begin{array}{l}1.50 \\
(0.30 \text { to } 2.70)\end{array}$ & $\begin{array}{l}2.31 \\
\text { (1.95 to } 2.66)\end{array}$ & $\begin{array}{l}0.23 \\
(0.16 \text { to } 0.30)\end{array}$ \\
\hline & Thang Long & $\begin{array}{l}2.82 \\
\text { (2.61 to } 3.02 \text { ) }\end{array}$ & $\begin{array}{l}-8.23 \\
(-9.23 \text { to }-7.22)\end{array}$ & $\begin{array}{l}0.96 \\
(0.76 \text { to } 1.16)\end{array}$ & $\begin{array}{l}1.49 \\
\text { (1.33 to } 1.66)\end{array}$ & $\begin{array}{l}0.13 \\
(0.06 \text { to } 0.20)\end{array}$ \\
\hline & Tourism & $\begin{array}{l}7.32 \\
\text { (2.58 to } 12.06)\end{array}$ & $\begin{array}{l}39.54 \\
\text { (32.11 to } 46.97 \text { ) }\end{array}$ & $\begin{array}{l}-66.66 \\
(-73.73 \text { to }-59.60)\end{array}$ & $\begin{array}{l}0.63 \\
(0.43 \text { to } 0.83)\end{array}$ & $\begin{array}{l}0.04 \\
(-0.04 \text { to } 0.11)\end{array}$ \\
\hline & Vinataba & $\begin{array}{l}1.60 \\
\text { (1.33 to } 1.87)\end{array}$ & $\begin{array}{l}8.71 \\
\text { (7.85 to } 9.58)\end{array}$ & $\begin{array}{l}0.09 \\
(0.07 \text { to } 0.11)\end{array}$ & $\begin{array}{l}-11.62 \\
(-12.60 \text { to }-10.64)\end{array}$ & $\begin{array}{l}0.49 \\
(0.41 \text { to } 0.56)\end{array}$ \\
\hline & Legal SE555 & $\begin{array}{l}0.92 \\
(0.71 \text { to } 1.14)\end{array}$ & $\begin{array}{l}4.40 \\
(3.72 \text { to } 5.08)\end{array}$ & $\begin{array}{l}0.03 \\
(0.02 \text { to } 0.04)\end{array}$ & $\begin{array}{l}2.84 \\
(2.30 \text { to } 3.39)\end{array}$ & $\begin{array}{l}-9.52 \\
(-9.59 \text { to }-9.44)\end{array}$ \\
\hline & Illicit SE555 & $\begin{array}{l}0.54 \\
(0.38 \text { to } 0.71)\end{array}$ & $\begin{array}{l}2.65 \\
\text { (1.96 to } 3.33)\end{array}$ & $\begin{array}{l}0.02 \\
(0.01 \text { to } 0.02)\end{array}$ & $\begin{array}{l}2.12 \\
(1.60 \text { to } 2.65)\end{array}$ & $\begin{array}{l}0.67 \\
(0.60 \text { to } 0.74)\end{array}$ \\
\hline & Opt-out & $\begin{array}{l}1.24 \\
(0.76 \text { to } 1.72)\end{array}$ & $\begin{array}{l}16.65 \\
\text { (11.91 to } 21.40)\end{array}$ & $\begin{array}{l}2.88 \\
\text { (1.86 to } 3.90)\end{array}$ & $\begin{array}{l}0.04 \\
(-0.00 \text { to } 0.07)\end{array}$ & $\begin{array}{l}0.01 \\
(-0.07 \text { to } 0.08)\end{array}$ \\
\hline & & Sai Gon & Bastos & Prince & White Horse & Legal SE555 \\
\hline \multirow[t]{8}{*}{ Central } & Sai Gon & $\begin{array}{l}-25.67 \\
(-27.36 \text { to }-23.98)\end{array}$ & $\begin{array}{l}2.36 \\
(2.18 \text { to } 2.54)\end{array}$ & $\begin{array}{l}11.14 \\
\text { (10.08 to } 12.20)\end{array}$ & $\begin{array}{l}7.05 \\
\text { (6.10 to } 8.01)\end{array}$ & $\begin{array}{l}0.15 \\
(-0.11 \text { to } 0.40)\end{array}$ \\
\hline & Bastos & $\begin{array}{l}6.85 \\
\text { (6.04 to } 7.66)\end{array}$ & $\begin{array}{l}-28.75 \\
(-31.04 \text { to }-26.46)\end{array}$ & $\begin{array}{l}11.89 \\
\text { (10.76 to } 13.01)\end{array}$ & $\begin{array}{l}4.59 \\
(3.97 \text { to } 5.21)\end{array}$ & $\begin{array}{l}0.13 \\
(-0.12 \text { to } 0.38)\end{array}$ \\
\hline & Prince & $\begin{array}{l}7.42 \\
(6.57 \text { to } 8.27)\end{array}$ & $\begin{array}{l}2.73 \\
(2.56 \text { to } 2.90)\end{array}$ & $\begin{array}{l}-23.57 \\
(-25.67 \text { to }-21.46)\end{array}$ & $\begin{array}{l}3.56 \\
(3.01 \text { to } 4.10 \text { ) }\end{array}$ & $\begin{array}{l}0.09 \\
(-0.17 \text { to } 0.34)\end{array}$ \\
\hline & White Horse & $\begin{array}{l}2.00 \\
(1.64 \text { to } 2.37)\end{array}$ & $\begin{array}{l}0.45 \\
(0.38 \text { to } 0.52)\end{array}$ & $\begin{array}{l}1.52 \\
\text { (1.26 to } 1.77)\end{array}$ & $\begin{array}{l}-4.65 \\
(-5.35 \text { to }-3.95)\end{array}$ & $\begin{array}{l}0.33 \\
(0.07 \text { to } 0.58)\end{array}$ \\
\hline & Legal SE555 & $\begin{array}{l}1.02 \\
(0.83 \text { to } 1.20)\end{array}$ & $\begin{array}{l}0.31 \\
(0.25 \text { to } 0.37)\end{array}$ & $\begin{array}{l}0.94 \\
(0.76 \text { to } 1.12)\end{array}$ & $\begin{array}{l}8.06 \\
(7.32 \text { to } 8.80)\end{array}$ & $\begin{array}{l}-10.73 \\
(-10.98 \text { to }-10.47)\end{array}$ \\
\hline & Illicit SE555 & $\begin{array}{l}0.61 \\
(0.47 \text { to } 0.74)\end{array}$ & $\begin{array}{l}0.26 \\
(0.19 \text { to } 0.33)\end{array}$ & $\begin{array}{l}0.73 \\
(0.54 \text { to } 0.92)\end{array}$ & $\begin{array}{l}5.24 \\
(4.46 \text { to } 6.01)\end{array}$ & $\begin{array}{l}0.37 \\
(0.12 \text { to } 0.63)\end{array}$ \\
\hline & Opt-out & $\begin{array}{l}3.00 \\
\text { (2.26 to } 3.75)\end{array}$ & $\begin{array}{l}1.10 \\
(0.87 \text { to } 1.33)\end{array}$ & $\begin{array}{l}8.93 \\
\text { (7.23 to } 10.64)\end{array}$ & $\begin{array}{l}0.33 \\
(0.22 \text { to } 0.45)\end{array}$ & $\begin{array}{l}0.00 \\
(-0.25 \text { to } 0.26)\end{array}$ \\
\hline & & Sai Gon & Hoa Binh & Khanh Hoi & Craven A & Legal SE555 \\
\hline \multirow[t]{9}{*}{ South } & Sai Gon & $\begin{array}{l}-35.60 \\
(-37.74 \text { to }-33.46)\end{array}$ & $\begin{array}{l}5.25 \\
\text { (4.63 to } 5.88 \text { ) }\end{array}$ & $\begin{array}{l}2.65 \\
\text { (1.94 to } 3.36)\end{array}$ & $\begin{array}{l}1.76 \\
\text { (1.44 to } 2.08)\end{array}$ & $\begin{array}{l}0.09 \\
(-0.75 \text { to } 0.92)\end{array}$ \\
\hline & Hoa Binh & $\begin{array}{l}15.28 \\
\text { (12.78 to } 17.78)\end{array}$ & $\begin{array}{l}-44.29 \\
(-47.91 \text { to }-40.67)\end{array}$ & $\begin{array}{l}2.85 \\
\text { (2.11 to } 3.59 \text { ) }\end{array}$ & $\begin{array}{l}1.77 \\
\text { (1.50 to } 2.03)\end{array}$ & $\begin{array}{l}0.10 \\
(-0.73 \text { to } 0.94)\end{array}$ \\
\hline & Khanh Hoi & $\begin{array}{l}18.17 \\
\text { (14.12 to } 22.21 \text { ) }\end{array}$ & $\begin{array}{l}6.72 \\
\text { (5.56 to } 7.89 \text { ) }\end{array}$ & $\begin{array}{l}-55.71 \\
(-61.29 \text { to }-50.12)\end{array}$ & $\begin{array}{l}1.32 \\
\text { (1.02 to } 1.61)\end{array}$ & $\begin{array}{l}0.05 \\
(-0.78 \text { to } 0.89)\end{array}$ \\
\hline & Craven A & $\begin{array}{l}2.33 \\
(1.84 \text { to } 2.83 \text { ) }\end{array}$ & $\begin{array}{l}0.80 \\
(0.64 \text { to } 0.97)\end{array}$ & $\begin{array}{l}0.25 \\
(0.18 \text { to } 0.33)\end{array}$ & $\begin{array}{l}-17.74 \\
(-19.59 \text { to }-15.89)\end{array}$ & $\begin{array}{l}0.73 \\
(-0.10 \text { to } 1.57)\end{array}$ \\
\hline & Legal SE555 & $\begin{array}{l}0.36 \\
(0.27 \text { to } 0.45)\end{array}$ & $\begin{array}{l}0.14 \\
(0.11 \text { to } 0.18)\end{array}$ & $\begin{array}{l}0.03 \\
(0.02 \text { to } 0.04)\end{array}$ & $\begin{array}{l}2.25 \\
(1.40 \text { to } 3.10)\end{array}$ & $\begin{array}{l}-9.92 \\
(-10.76 \text { to }-9.08)\end{array}$ \\
\hline & Illicit SE555 & $\begin{array}{l}0.11 \\
(0.08 \text { to } 0.15)\end{array}$ & $\begin{array}{l}0.04 \\
(0.03 \text { to } 0.06)\end{array}$ & $\begin{array}{l}0.01 \\
(0.00 \text { to } 0.01)\end{array}$ & $\begin{array}{l}0.81 \\
(0.59 \text { to } 1.03)\end{array}$ & $\begin{array}{l}0.73 \\
(-0.10 \text { to } 1.57)\end{array}$ \\
\hline & Hero & $\begin{array}{l}6.87 \\
\text { (5.75 to } 7.99 \text { ) }\end{array}$ & $\begin{array}{l}2.15 \\
\text { (1.83 to } 2.47)\end{array}$ & $\begin{array}{l}0.67 \\
(0.52 \text { to } 0.81)\end{array}$ & $\begin{array}{l}2.12 \\
\text { (1.88 to } 2.36)\end{array}$ & $\begin{array}{l}0.25 \\
(-0.59 \text { to } 1.08)\end{array}$ \\
\hline & Jet & $\begin{array}{l}2.37 \\
(1.95 \text { to } 2.79)\end{array}$ & $\begin{array}{l}0.67 \\
(0.56 \text { to } 0.78)\end{array}$ & $\begin{array}{l}0.15 \\
(0.12 \text { to } 0.18)\end{array}$ & $\begin{array}{l}2.24 \\
\text { (1.90 to } 2.57)\end{array}$ & $\begin{array}{l}0.43 \\
(-0.41 \text { to } 1.26)\end{array}$ \\
\hline & Opt-out & $\begin{array}{l}4.26 \\
\text { (3.02 to } 5.50)\end{array}$ & $\begin{array}{l}1.57 \\
\text { (1.15 to } 2.00)\end{array}$ & $\begin{array}{l}1.43 \\
\text { (1.04 to } 1.82)\end{array}$ & $\begin{array}{l}0.08 \\
(0.06 \text { to } 0.10)\end{array}$ & $\begin{array}{l}0.00 \\
(-0.83 \text { to } 0.84)\end{array}$ \\
\hline
\end{tabular}

brands and 3.0\% for high-priced legal ones) would not consume legal cigarette brands any longer. Among them, although around $7 \%$ (less than a half) would switch to illicit brands, the remaining $8 \%$ would choose none of the experimented brands, suggesting smokers' probable intent to quit.

Furthermore, the magnitude of substitution to illicit brands tends to be negatively related to change in their prices as a result of the specific excise tax hike. Should the illicit brand prices go up by $50 \%$ of the 5000 Vietnamese dong specific tax $(2500$ Vietnamese dong) (scenario 2), then their total market share would increase by only less than four percentage points, half of the figure in scenario 1, where their prices are assumed to be constant. Understandably, once the illicit cigarettes become more expensive, not only do they appear less compelling as substitutes, but some of their current smokers may also find them no longer affordable and would choose not to stay with them.

The impact of tax increases also varies with the extent to which they are passed through to smokers by the tobacco industry. In the third scenario, where the pass-through rate is assumed to be heterogeneous across brands, the results change slightly, compared with those in the baseline. The low-priced licit brands are less impacted due to their lower after-tax prices. The high-priced licit brands lose more, but the additional decrease in their market share is less than the amount saved for the low-priced licit brands, thereby resulting in a smaller total decrease in the market share of the taxed brands. The improvement in the market shares of illicit brands and opt-out is slightly smaller.

When the excise taxes are undershifted and the prices of illicit cigarettes rise, the extent to which the illicit cigarettes' market share increases is smaller than in the second scenario. The 5000 Vietnamese dong specific tax could result in about 2.4 percentage points higher in their market share, compared with 3.7 percentage points in the second scenario. Meanwhile, the legal brands, both low-priced and high-priced, exhibit a smaller reduction in their market share while the market share gain accruing to the opt-out also decreases. These results highlight the influence of brand-switching behaviour on the impact of tobacco tax policies on brand choice, which must be taken into consideration when one evaluates any tax reform. 


\begin{tabular}{|c|c|c|c|c|c|c|}
\hline \multirow[b]{2}{*}{ Price segment } & \multicolumn{2}{|c|}{1000 Vietnamese dong specific tax } & \multicolumn{2}{|c|}{2000 Vietnamese dong specific tax } & \multicolumn{2}{|c|}{5000 Vietnamese dong specific tax } \\
\hline & Mean & $95 \% \mathrm{Cl}$ & Mean & $95 \% \mathrm{Cl}$ & Mean & $95 \% \mathrm{Cl}$ \\
\hline \multicolumn{7}{|l|}{ Scenario 1} \\
\hline Low & -3.31 & -3.67 to -2.95 & -6.11 & -6.76 to -5.45 & -11.90 & -13.06 to -10.75 \\
\hline High & -0.70 & -0.78 to -0.61 & -1.36 & -1.53 to -1.18 & -3.04 & -3.43 to -2.65 \\
\hline Illicit SE555 & 0.12 & 0.10 to 0.13 & 0.25 & 0.21 to 0.28 & 0.72 & 0.62 to 0.83 \\
\hline Jet and Hero & 4.19 & 3.72 to 4.65 & 7.90 & 7.01 to 8.80 & 14.63 & 13.06 to 16.19 \\
\hline Opt-out & 2.06 & 1.77 to 2.35 & 3.77 & 3.26 to 4.28 & 7.83 & 6.87 to 8.79 \\
\hline \multicolumn{7}{|l|}{ Scenario 2} \\
\hline Low & -2.75 & -3.06 to -2.43 & -5.14 & -5.71 to -4.57 & -10.80 & -11.90 to -9.70 \\
\hline High & -0.40 & -0.45 to -0.36 & -0.80 & -0.90 to -0.71 & -2.00 & -2.25 to -1.74 \\
\hline Illicit SE555 & 0.06 & 0.05 to 0.07 & 0.13 & 0.11 to 0.15 & 0.34 & 0.30 to 0.39 \\
\hline Jet and Hero & 2.11 & 1.87 to 2.36 & 3.97 & 3.49 to 4.45 & 7.60 & 6.61 to 8.60 \\
\hline Opt-out & 2.16 & 1.86 to 2.47 & 4.08 & 3.53 to 4.63 & 9.13 & 8.04 to 10.23 \\
\hline \multicolumn{7}{|l|}{ Scenario 3} \\
\hline Low & -2.49 & -2.78 to -2.19 & -4.68 & -5.24 to -4.13 & -9.50 & -10.56 to -8.45 \\
\hline High & -0.89 & -0.98 to -0.81 & -1.72 & -1.90 to -1.55 & -3.80 & -4.19 to -3.41 \\
\hline Illicit SE555 & 0.11 & 0.09 to 0.12 & 0.22 & 0.19 to 0.26 & 0.64 & 0.55 to 0.74 \\
\hline Jet and Hero & 3.63 & 3.25 to 4.02 & 6.97 & 6.21 to 7.72 & 13.76 & 12.29 to 15.24 \\
\hline Opt-out & 1.69 & 1.45 to 1.92 & 3.14 & 2.71 to 3.57 & 6.65 & 5.81 to 7.48 \\
\hline \multicolumn{7}{|l|}{ Scenario 4} \\
\hline Low & -2.11 & -2.36 to -1.86 & -4.01 & -4.47 to -3.55 & -8.77 & -9.71 to -7.83 \\
\hline High & -0.26 & -0.29 to -0.23 & -0.53 & -0.59 to -0.47 & -1.34 & -1.50 to -1.18 \\
\hline Illicit SE555 & 0.04 & 0.03 to 0.04 & 0.08 & 0.07 to 0.09 & 0.21 & 0.18 to 0.24 \\
\hline Jet and Hero & 1.29 & 1.14 to 1.45 & 2.46 & 2.15 to 2.76 & 5.01 & 4.31 to 5.71 \\
\hline Opt-out & 1.77 & 1.52 to 2.02 & 3.38 & 2.92 to 3.85 & 7.72 & 6.76 to 8.68 \\
\hline
\end{tabular}

Jet and Hero are exclusively concentrated in the South. Each number indicates a change (in percentage points) in market share in the country. One percentage point represents $1 \%$ of the total number of current smokers.

According to the World Bank, the average official exchange rate in 2019 was 1.00 Vietnamese dong $=$ US $\$ 4.34 \times 10^{-5}$ or US $\$ 1.00=23050.24$ Vietnamese dong.

\section{CONCLUSION AND POLICY RECOMMENDATIONS}

The study uses the state-of-the-art combination of choice experiment data and real market data to study the brand-switching behaviour of smokers in response to a price increase and estimate the potential impact of different tobacco tax reform proposals under consideration on brand-level market share. It shows that faced with price increases, smokers generally switch to close substitutes-higher-priced domestic brand smokers switch to other lower-priced domestic brands, while upgrading from domestic brands to foreign brands is not prominent. Furthermore, imposing a specific tax reduces the market share for both low-priced and high-priced licit brands, and the estimated market share reduction is larger for low-priced licit brands than for high-priced licit brands. This is consistent with findings in the USA ${ }^{26}$ and China. ${ }^{14}$ The main reason is that the introduction of a uniform specific tax results in a higher percentage change in price for low-priced licit brands than for high-priced licit brands. Furthermore, smokers of low-priced licit brands are more pricesensitive than smokers of high-priced licit brands. Therefore, the market share for low-priced licit brands will be more impacted.

A large share of smokers substituting away from domestic brands refused to purchase any of the studied cigarette brands (accounting for a market share of over 80\%), rather than up-trade to the foreign brands or to illicit brands. One of the main reasons why smokers choose to smoke domestic brands has to do with their limited budgets. When cigarette prices increase, smokers of more expensive, foreign brands can trade down to more affordable, domestic brands to maintain their consumption and mitigate rising smoking expenses. Smokers of domestic brands however cannot do this. With tighter budget constraints, many of them therefore may not be able to afford higher cigarette expenditures, and consequently have no choice but to opt for other tobacco products or strive to quit smoking. Nevertheless, in response to the tax increase, some smokers of domestic and foreign brands may switch to illicit brands, mainly Jet and Hero in the South, resulting in a higher market share for illicit cigarettes. Yet this market share gain is relatively sensitive to how the prices of illicit cigarettes respond to the tax increase. The more their prices rise, the smaller the gain is.

The results have two policy implications. First, the government of Vietnam should switch from a purely ad valorem tobacco excise tax scheme to a mixed system. While adding a specific component would impact domestic tobacco companies more, it is effective in disincentivising smokers from smoking, particularly smokers of low-priced domestic brands. Since the poor are more likely to choose these products, it can benefit them more than the rich and make tobacco taxation more progressive. Second, the government of Vietnam should maintain and strengthen intensive and effective market surveillance and border control led by the 389 Steering Committee and its provincial affiliates, which specialise in fighting against smuggling. By increasing the cost of sourcing, distributing and purchasing illicit cigarettes, and thus their prices in the South and economic centres, these activities will not only obstruct substitution from licit to illicit cigarettes, but also encourage current smokers of illicit cigarettes to quit. Market monitoring also helps understand the extent to which the tax increase is passed through to retail prices, which determines the impact of the tax increases.

This research is subject to several limitations. First, the experiment design assumes that illicit brands are easily accessible to smokers and that their prices are unchanged. In reality, both their price and availability depend on a number of factors, 
including the strategic responses from illicit traders, the efforts expended by the government to combat smuggling and policy changes in neighbouring countries. In particular, the accessibility of the illicit brands is more limited so that it may be harder for smokers to purchase them. Consequently, the model may overestimate the impact of increasing taxes on illicit trade, while at the same time underestimate the effectiveness of increasing taxes in reducing cigarette consumption. Second, although the opt-out option 'none of these' is included, the probability of quitting is not explicitly considered in the model. Apart from smoking cessation, smokers may choose not to buy any of the considered brands because, for example, they may delay their purchases or choose to switch to other more affordable tobacco products other than cigarettes. Third, the choice experiment may not be completely free from hypothetical bias, even though smokers having good knowledge of cigarette brands other than those they were smoking at the time of survey can help reduce this. ${ }^{27}$

\section{What this paper adds}

- Imposing a specific excise tax on tobacco products has proven more effective in reducing cigarette consumption as it tends to raise overall cigarette price levels more than does the ad valorem.

- One concern against adding a specific excise in Vietnam is that it may shift consumption away from domestic brands to foreign brands and to illicit cigarettes, thus impairing the domestic industry, rather than reducing cigarette consumption effectively.

- No study thus far has attempted to address the issue due mostly to the unavailability of relevant micro-market data with detailed information on brand choice.

- This research is the first attempt to study cigarette brand substitution patterns and quantify the potential effect of adding a specific component on the existing purely ad valorem system in Vietnam by conducting a discrete choice experiment.

Acknowledgements We would like to thank our colleagues at DEPOCEN for their efforts in implementing the experiment in 2019. We also thank Professor Frank J Chaloupka, Dr Ce Shang, Dr Maryam Mirza and Dr Evan Blecher for their helpful comments. We also thank two anonymous reviewers for their constructive comments. All errors are our own.

Contributors All authors designed the experiment. AN oversaw the project and finalised the manuscript. HNT analysed data and wrote an earlier draft of the manuscript. NAN coordinated the implementation of the experiment in the field and cleaned primary data. All authors were involved in revising the paper. AN is responsible for the overall content as guarantor.

Funding The project, including the data collection, is financially supported by the University of Illinois at Chicago's Institute for Health Research and Policy through its partnership with Bloomberg Philanthropies.

Competing interests None declared.

Patient consent for publication Not required.

Ethics approval The discrete choice experiment in 2019 was conducted with ethics clearance from the Institutional Ethics Review Board at Hanoi School of Public Health, Vietnam.

Provenance and peer review Not commissioned; externally peer reviewed.

Data availability statement Data are available upon reasonable request. Data requests should be addressed to the authors by email.

Supplemental material This content has been supplied by the author(s). It has not been vetted by BMJ Publishing Group Limited (BMJ) and may not have been peer-reviewed. Any opinions or recommendations discussed are solely those of the author(s) and are not endorsed by BMJ. BMJ disclaims all liability and responsibility arising from any reliance placed on the content. Where the content includes any translated material, BMJ does not warrant the accuracy and reliability of the translations (including but not limited to local regulations, clinical guidelines, terminology, drug names and drug dosages), and is not responsible for any error and/or omissions arising from translation and adaptation or otherwise.

\section{ORCID iD}

Anh Nguyen http://orcid.org/0000-0003-2753-2667

\section{REFERENCES}

1 WHO. Who report on the global tobacco epidemic 2019: offer help to quit tobacco. WHO, 2019.

2 Thúy H. Hiệp hội thuốc lá Việt NAM: 30 năm đồng H NH cùng doanh nghiệp. Báo Công Thương, 2019. Available: https://congthuong.vn/hiep-hoi-thuoc-la-viet-nam-30nam-dong-hanh-cung-doanh-nghiep-121342.html [Accessed 27 Jul 2021].

3 Regmi K, Kaphle D, Timilsina S, et al. Application of Discrete-Choice experiment methods in tobacco control: a systematic review. Pharmacoecon Open 2018;2:5-17.

4 Kotnowski K, Fong GT, Gallopel-Morvan K, et al. The impact of cigarette packaging design among young females in Canada: findings from a discrete choice experiment. Nicotine Tob Res 2016;18:1348-56.

5 Marti J, Buckell J, Maclean JC, et al. To "vape" or smoke? Experimental evidence on adult smokers. Econ Inq 2019;57:705-25.

6 Kenkel D, Peng S, Pesko M. Mostly harmless regulation? electronic cigarettes. Cambridge, MA: Public Policy and Consumer Welfare, 2019.

7 Shang C, Huang J, Chaloupka FJ, et al. The impact of flavour, device type and warning messages on youth preferences for electronic nicotine delivery systems: evidence from an online discrete choice experiment. Tob Control 2018;27:e152-9.

8 Train KE. Discrete choice methods with simulation. 2 edn. Cambridge University Press, 2009

9 Louviere JJ, Hensher DA, Swait JD. Stated choice methods. Cambridge University Press, 2000

10 Evans WN, Farrelly MC. The compensating behavior of smokers: taxes, TAR, and nicotine. Rand J Econ 1998:29:578-95.

11 Tsai Y-W, Yang C-L, Chen C-S, et al. The effect of Taiwan's Tax-induced increases in cigarette prices on brand-switching and the consumption of cigarettes. Health Econ 2005; 14:627-41

12 Li J, White JS, Hu T-W, et al. The heterogeneous effects of cigarette prices on brand choice in China: implications for tobacco control policy. Tob Control 2015;24 Suppl 3:iii25-32.

13 White JS, Ross H. Smokers' strategic responses to Sin taxes: evidence from panel data in Thailand. Health Econ 2015;24:127-41.

14 Liu H, Rizzo JA, Sun Q, et al. How do smokers respond to cigarette taxes? Evidence from China's cigarette industry. Health Econ 2015;24:1314-30.

15 WHO. Who technical manual on tobacco Tax administration. Geneva, 2010.

16 Hensher DA, Rose JM, Greene WH. Applied choice analysis: a primer. Cambridge: Cambridge University Press, 2005.

17 Nguyen A, Nguyen HT. Tobacco excise tax increase and illicit cigarette consumption: evidence from Vietnam. Tob Control 2020:29:tobaccocontrol-2019-055301

18 WHO. Tobacco taxes in Viet Nam questions and answers. Hanoi, 2018.

19 Chiou L, Muehlegger E. Consumer response to cigarette excise tax changes. Natl Tax J 2014;67:621-50

20 Harding M, Leibtag E, Lovenheim MF. The heterogeneous geographic and socioeconomic incidence of cigarette taxes: evidence from nielsen homescan data. Am Econ J Econ Policy 2012:4:169-98.

21 Espinosa J, Evans WN. Excise taxes, Tax incidence, and the flight to quality. Public Finance Rev 2013:41:147-76

22 DeCicca P, Kenkel D, Liu F. Who pays cigarette taxes? the impact of consumer price search. Rev Econ Stat 2013:95:516-29.

23 Sullivan RS, Dutkowsky DH. The effect of cigarette taxation on prices: an empirical analysis using Local-Level data. Public Finance Rev 2012:40:687-711.

24 Hanson A, Sullivan R. The incidence of tobacco taxation: evidence from geographic micro-level data. Natl Tax J 2009;62:677-98.

25 Cevik S. Smoke screen: estimating the Tax pass-through to cigarette prices in Pakistan Rev Dev Econ 2018:22:e1-15.

26 Sobel RS, Garrett TA. Taxation and product quality: new evidence from generic cigarettes. J Polit Econ 1997;105:880-7.

27 Morwitz VG, Steckel JH, Gupta A. When do purchase intentions predict sales? Int $J$ Forecast 2007:23:347-64. 